\title{
A CONSIDERATION OF JOHN OWEN'S TEACHING ON THE HEAVENLY SESSION OF CHRIST
}

\author{
DINU MOGA*
}

Emanuel University of Oradea

\begin{abstract}
Owen's writings on this subject helps us to see in a profound way that every aspect of Christ's work is based upon an act of divine love and good pleasure in which Christ has come to us in order to restore us to fellowship with God. The Divine counsel stands at the basis of Owen understanding of Christ mediatorial work. In all their aspects, Owen's Christological reflections represent a restatement of orthodox Christology which stands in fundamental continuity with the Reformed tradition, particularly in its use of the threefold office of Christ. What emerges in Owen regarding Christ as Mediator is positively shaped by the intratrinitarian relations defined by the covenant of redemption and the three-fold office of Christ as prophet, priest, and king which preserve both, the historical and the eternal dimensions. There is nothing more demanded from the church of the present day than the revival of the idea the we live in him who is our High Priest in heaven.
\end{abstract}

KEY WORDS: Christology, Reformed tradition, office, mediatorial, High Priest

\section{Introduction. Owen, His Theology, Purpose, and Work}

Any study of John Owen's work on the Person of our Lord Jesus Christ will prove to every reader today that he has been and still remains a theologian who is worthy to be examined and admired for his deep evangelical and biblical convictions. Owen is able to offer us, as has been recently stated, 'the all too rare combination of the sharpness of intellect required in the academy, with the largeness of heart and spirit required for growth in the knowledge of our Lord Jesus Christ' (Ferguson 2002: 71-72).

The same writer continues to show how Owen's own pursuit was to place his intellectual learning in tribute to his pursuit of a personal knowledge of the person of Jesus Christ. This is, of course, a principal which ought to be guiding us all today when so much is available to us in the area of Christology and so little comes out of deeply evangelical convictions.

* DINU MOGA (MTh in Historical Theology, Westminster Theological Seminary, 2005; PhD in Theology, Babeș-Bolyai University, 2015) teaches Systematic and Historical Theology at Emanuel University of Oradea. Email: mogadinu@gmail.com. 
When Owen examines the doctrine of the Trinity, which for him is fundamental for every aspect of our salvation (Trueman 2002: 59-61), his main topic of debate is the Person and work of Christ. For Owen Christology is the main subject of his interest due to its rejection by the Socinians and the authors of the Racovian Catechism (Trueman 1998: 151-154). In his Vindiciae Evangelicae Owen proves to be an able writer within a polemical context and gives an exhaustive and critical response to Socinianism. And he does this through a critical and devastating response to John Biddle's version of the Catechism. In all these circumstances Owen's interest is to undermine false foundations in order that he might place Jesus Christ in the hearts and minds of those for whom he writes.

Once we have said this about Owen, although so much more could be said, our next aim will be to see what sort of Christ Owen is concerned to present his readers.

It has been stated, against various theories underlying the onedimensional aspect of Christ's work, that the work of Christ is multidimensional in form and multivalent in function' (Ferguson 2002: 94). For Owen the background to every aspect of Christ's work is that it is an act of divine love, or good pleasure, in which Jesus Christ comes to us as the Second Man and the Last Adam, first to restore individual sinners and an entire people to fellowship with God, and then to bring a restored, reconstituted and glorious universe into being-one that surpasses creation in its original form. Christ came into our world to save sinners, to restore the universe to its stability and to fill it with glory, and hence to bring the family from heaven and the family on earth together as one glorious fellowship of which he himself is the Head. [Expounding against the background of Paul's teaching in Ephesians 1:20-22 and Colossians 1:15-20 Owen is convinced that in the original creation God brought into being two families, one angelic in heaven one human on earth, distinct from each other, who had sinned and fell, the former only in part and the second in its entirety. But God's plan was to decree to preserve the fallen angels and to save a remnant of those who had fallen in the human family (Owen Works I: 36774).]

Owen continues to explain that the Son of God does reconciliation through atonement as obedience. Christ became obedient to the Law of God as he discharged his three-fold office in terms of a substitution of his obedience for our disobedience.

As we progress in the study of Christ, we find in Owen's work that there is a basic structure in the explanation of his christological convictions. First, Owen regards Christ as both God and man united in one person. Secondly, Christ fulfils his saving ministry in a two-dimensional way: in his fulfilment of the three-fold office, Prophet, King and Priest, and in his experience of a 
two-fold state, the state of humiliation and the state of exaltation. And thirdly, Christ does all these specifically for the sake of the elect. These are three fundamental assertions which will, in the course of this study, come often to the forefront of our discussions.

Within the same mediatory context of Christ, Owen continues to imply, in general, two important things about Him. The first of these two things is that Christ should have a human nature, because in his divine nature, singly considered, he had no such relation unto them for whom he was to discharge his offices, as was necessary to communicate the benefit of them, nor could he discharge their principal duties' (Owen Works I: 86). His clear conclusion is that God could not die in his divine nature. Therefore, explains Owen, God prepared a body for him-that is, a human nature (Hebrews 10:5). If such would have not been the case, maintains Owen, 'we could have received no benefit... by any office that he could have undertaken'. (Owen Works I: 87).

But the second important thing is that Christ had to be also divine, because He had to be able 'to render his offices effectual unto their proper ends' (Owen Works I: 87). With respect to all of Christ's offices, Owen stresses the fact that none of them could have been rendered effectual had he been no more that a man. His conclusion, therefore, is that Christ had to be more than mere human, because he had to mediate between humanity and God.

Owen's treatment on the Person of Christ receives a detailed exegetical attention in various places of his works, but predominantly in his mammoth Exposition of the Epistle to the Hebrews (volumes 18-24 in the original Goold edition of the Works, Edinburgh 1854-1855). In the essays which precede the actual commentary, and in the exposition of the text itself, Owen expounds the centrality of the priesthood of Christ in the work of reconciliation. Then in his great work Christologia (1679, in Works I: 1-272) Owen sets out in a more formal way to give expression to the doctrine of Christ's Person and then in a more meditative, contemplative fashion in the posthumously published Meditations on the Glory of Christ (part one 1684, part two 1689) (Owen Works I: 274-463). These works mark the starting point of his greater works unravelled later with the distinction that in his later works the language is obviously more technical, theological and clearly more expository and devotional.

\section{Heavenly Session of Christ in Owen's Writings}

As we move from an introduction into Owen's Christology the intention will be to narrow gradually our discussion to that aspect of Christ's work which makes the subject of our study. We shall refer, therefore, in greater details to that which in Owen's own words is defined as 'The exercise of the mediato- 
ry office of Christ in heaven' (Owen Works I: 252-272) and in doing so we are interested to examine the character of Christ's work. What sort of work does Christ do in heaven and for whom is he doing it? Before we offer an answer to these questions, it will be appropriate to say a few things about the context in which Christ's mediatorial work is presented, the three-part mediatorial offices and then, the actual exercise of his office in heaven. We shall finally complete our study with a brief examination of more recent discussions

\section{The Context of Christ's Mediatorial Work in Heaven}

It must be asserted from the outset that Owen's treatment on the Person of Christ is always made within the context of the Trinity. The Son is sent by the Father and performs His task through the Holy Spirit.

But, commenting on Owen's treatment on Christology, Trueman notes that in his treatise on the work of Christ Owen makes use of two basic patterns existed within the tradition of Reformed Orthodoxy: 'that of the two states of humiliation and exaltation and that of the threefold office' (Trueman 1998:165).

Owen himself regards the threefold office of Christ as the basis of Christ's mediatorial dealing with the church when he says: 'It is by the exercise and discharge of the office of Christ - as the king, priest, and prophet of the church-that we are redeemed, sanctified and saved' (Owen Works I: 85). The effects of such work are immediate, says Owen, and 'give us an access unto God here by grace, and in glory hereafter' (Owen Works I: 85).

But in all of Owen's theological treatments on the Person of Christ we also see an intimate connection between the eternal and historical dimensions of Christ's work.

In his comments on the same matters, Trueman explains that Owen develops his thought in a way so as to retain the integrity of both the eternal and historical dimensions of salvation while clearly pointing out their mutual dependence. While it is true, continues Trueman, that the eternal covenant provides the causal ground for Christ's mediation, it cannot be interpreted as weakening the importance of the incarnation, or of Christ's historical ministry, because the very being of God which stands behind the covenant requires that the Son assume human flesh if salvation is to be accomplished. What this all means is that the covenant of redemption and the act of incarnation are equally vital and mutually dependant on each other in the overall structure of salvation (Trueman 1998: 192).

\section{Christ's Three Part Mediatorial Offices in Heaven}

When the prophetic work of Christ is analysed, we notice how Owen gives it a Trinitarian framework. [Reference is made here to Owen's three question catechism in Owen Works I: 483. The trinitarian work is seen in these ques- 
tions in the fact that the Son is sent by the Father and perform his task through the Spirit (Trueman 1998: 170).] The purpose of Christ's prophetic office is to reveal the will of the Father. Christ knows the will of the Father and in order to be able to communicate it to humans He must stand in a relationship which facilitates that communication. Owen explains that as Christ has ascended to heaven, He continues his prophetic office in this world exclusively via the Word and the Spirit. When Jesus' teaching is examined in the New Testament, especially the one expounded in John 14-16, it becomes obvious that the continuing presence and the work of the Spirit within the believing community, are entirely dependent upon the presence in heaven of the exalted Lord. It is exactly this achievement and glorification that enables the Father to send his Spirit into the world. [For a more detailed exposition on Christ's prophetic office continued from heaven through the Spirit, see Toon (1984: 76ff).]

When Owen deals with Christ's kingly office his concern is to establish a correct understanding of this office as it relates to the doctrine of the two states of Christ. It becomes clear from his writings that Owen sees God the Son to be always king even during the humiliation as the incarnate Logos. This is what he asserts:

As For his exaltation at his ascension, it was not by any investiture in any new office, but by an admission to the execution of that part of his work of mediatorship which did remain, in a full and glorious manner, the whole concernment of his humiliation being past. In the meantime, doubtless, he was a king when the Lord of glory was crucified, 1 Corinthians 2:8 (Owen Works XII: 373).

For Owen Christ is king before his incarnation, which stresses, on the one hand, that Christ is king and sovereign by nature, as he is God, and, on the other hand, that Christ is king and sovereign by delegation, within the structure of mediation (Owen Works XII: 374-375).

When Trueman discusses the inauguration of Christ's kingly office he sets it within the context of these two states and therefore represents it as part of the exaltation after humiliation. Quoting Owen on this subject, Trueman comes to an important conclusion about the three mediatorial offices of Christ. He says:

...the admission to the regal office does not involve some kind of ontological change on the part of the Son. It represents rather a particular phase in the historical economy of salvation, an economy which derives its unity from the fact that each of the offices of prophet, priest, and king are not really a separate office but that the three offices are three parts of one task of mediation (Trueman 1998: 180, 181). 
And then, with respect only to his kingly office, Trueman concludes: 'the role of Christ as king in terms of guarding and guiding the church belongs to him as much by the fact that he is God as by the fact that he is Mediator' (Trueman 1998: 180, 181; see also Owen (Works XX: 98).

In terms of practical things Owen's discussion of the kingly office is significant not only for understanding the work of Christ as Mediator in a purely doctrinal sense, but also in understanding the link that there is between doctrine and piety. [For the connection which exists between doctrine and piety in the context of Christ's kingly office see details in Trueman (1998: 183-185).] Once this is established it becomes even more evident that the first two mediatorial offices, the prophetic and kingly offices, point towards a deeper need for humanity: the need to deal with the objective problem of sin and its consequences upon the believer. These issues are only resolved when the third part of the mediatorial office is taken into consideration: the high priesthood of Christ.

When Owen's theological assertions regarding Christ's priestly office are examined the following observations need to be mentioned. Owen discusses the priestly office of Christ within the context of Christ's death. Christ's death becomes an action taken by him in his role as the great high priest. So, the priesthood of Christ involves an understanding of the nature of Christ's death and its relationship to salvation and to the church. It is obvious, therefore, that Owen treats atonement as part of the high priestly office of Christ.

This priestly role is itself set within the context of his role as Mediator; and this mediatorial role is set within the context of the two economies of salvation, the eternal and the historical, which find expression in the intratrinitarian covenant relations and the incarnation.

As Christ's priesthood is just one aspect of his role as Mediator, so his appointment to the office is, in the same way as his appointment to the offices of prophet and king, simply one aspect of his appointment as Mediator. Thus, the eternal and the historical economies are again of crucial importance: Christ's high priesthood finds its ultimate causal ground in the intratrinitarian covenants, and its historical inauguration in the earthly ministry of Christ.

The dynamic nature of Owen's Christology is once again explicit in the notion of historical movement within Christ's role as Mediator: while the causal ground of Christ's mediation lies in the eternal covenant, this does not serve to eclipse the importance of Christ's entry into history. The eternal dimension does not swallow up time, but it requires it in order to give meaning and purpose to Christ's historical person and ministry. Thus, the incarnate acts of Christ are important. Considering the reality of sin and of God's desire to save, the incarnation of Christ is absolutely necessary. 
In this context, citing Hebrews 5:4-6 as evidence, Owen does not hesitate to see the covenant as constituting the call of Christ to the office. This is what Owen has to say in that respect:

In general, I say, that the call of Christ unto the office of the priesthood consisted in that eternal covenant which was between the Father and him concerning his undertaking the work of our recovery and salvation (Owen Works XVIII: 15ff, 152).

This, of course, confirms that it is the eternal covenant which is both the causal ground of Christ's priesthood and, therefore, the basic theological structure which defines the nature of that priesthood. Owen's work on Hebrews covers not only extensive exegesis of passages which speak of Christ's priesthood, but also an extended preliminary essay on this topic which serves to draw together the various doctrinal issues.

For Owen, the nature of priesthood is encapsulated in Hebrews 5:1. This verse defines two basic criteria for anyone who is to be a priest: he has to be from among the people; and he has to be appointed to act on behalf of others in the matters of God (Owen Works XVIII: 16-17; cf. Owen Works XII: 398-399; Milligan 1977: 103ff).

These two aspects of priesthood can be found in Christ's incarnation, whereby Christ as man can be said to be taken from among the people, and in the covenant of redemption, whereby the Father appoints the Son as Mediator, and the Son willingly accepts the office.

Given all that has been said so far concerning both the eternal causal ground of Christ's mediation in the covenant of redemption, and the historical movement within his incarnate life as Mediator, it should be no surprise that the key element to understanding the priestly office of Christ is to be found in the interrelationship between the eternal and the historical dimension. Therefore, we conclude that Christ's priesthood should not be separated or considered in isolation from either its cause in the eternal covenant of redemption, or its means in the incarnation and work of Christ.

\section{The Exercise of Christ's Mediatory Office in Heaven}

We start here with the central verse in Owen's treatment on the priesthood of Christ, Hebrews 5:1. The author of the epistle to the Hebrews tells us clearly that while on earth Christ offered himself a sacrifice to God upon the cross. But we must maintain that Christ's sacrifice on the cross constitutes a part of his priestly function which is not continued in the heavens. This truth is strongly confirmed by the same epistle when it says: "who does not need daily, as those high priests, to offer up sacrifices, first for his own sins and then for the people for this he did once for all when he offered up himself' (Hebrews 7:27; cf. Hebrews 9:12; 9:25, 26). 
However, this does not mean that Christ discontinued his priestly office and function in heaven. At this point, Owen makes us aware of the need to appreciate the continuity and inter-dependence of our Lord's earthly and heavenly ministries. He calls this 'a principal article of the faith of the church' (Owen Works I: 235ff). In heaven, exalted above the whole creation in a state of the highest glory, Christ leads a life, not of mere glory, majesty and blessedness, but a life of office, love and care (Owen Works I: 252).

When the structure of Christ's oblation on earth is taken into, Owen parallels it with Christ's intercession in heaven. It began on earth, with oral prayers, it now continues in heaven in a virtual, or real sense, whereby Christ directly intercedes with the Father in a transcendent way without the use of language. Here is what Owen says:

The earthly and heavenly intercession of Christ are fundamentally continuous, the difference laying in the mode not the content: the whole matter of words, prayers, and supplications, yea, of internal conceptions of the mind formed into prayers, is but accidental unto intercession, attending the state and condition of him the intercedes. The real entire nature of it consists in the presentation of such things as may prevail in the way of motive or procuring cause with respect unto the things interceded for. And such do we affirm the intercession of Christ as our high priest in heaven to be (Owen Works XVIII: 197).

Once again, the notion of historical movement is not swallowed up by, or radically subordinated to, the eternal dimensions of salvation, but rather helps to focus and define Christ's role as Mediator.

The very essence of the Epistle to the Hebrews is that Jesus Christ is a priest for ever after the order of Melchizedek: 'But he, because he continues for ever, has an unchangeable priesthood' (Hebrews 7:24). It results from here that there must be a high priestly activity continually carried on by Jesus in the heavenlies, in what the writer to the Hebrews calls 'at the right hand of the throne of the Majesty in the heavens' (Hebrews 8:1).

Thus, Owen establishes for all those men who poses 'only a general and confused notions and apprehensions of the present state of Christ, with respect unto the church' (Owen Works I: 252), the strong fact that in heaven Christ lives as the Mediator of the church: as the King, Priest, and Prophet. In heaven Christ seats in all his power and glory and mediates on behalf of the people of God.

This truth is further illustrated by Owen from the book of Revelation which introduces Christ as the Lamb that has been slain, the One who walks as high priest in the midst of the seven golden candlesticks and in that capacity, he addresses the seven churches in Asia. Truly Christ executes his kingly office as head over all things for the benefit of his body the church. But while Christ is a priest he is a priest upon his throne. We emphasise this 
aspect because we must not allow the consideration of his kingly office to eclipse the aspect of Christ's heavenly activity as priest. So, we speak here about that which John Murray calls 'an inter-permeation of the various offices' (Murray 1958: 5). Owen explains it in the following words:

The call of Christ unto his offices of king, priest and prophet, as it respects the authority and love of the Father, was but one and the same. He had not a distinct call unto each office, but was at once called unto them all, as he was the Son of God sent and anointed to be Mediator between God and men. The offices themselves, the gifts and graces to be exercised in them, their powers, acts and duties, were distinct, but his call unto them all was the same (Owen Works XVIII: 182).

This brings us in Owen's treatment to some important questions: What is this high priestly activity in heaven? And how does he perform this office? (Owen Works I: 254).

First, Owen shows that as high priest Christ entered into the heavens as into a temple or a place of sacred worship. The place where Christ enters in heaven has already been prefigured by the Old Testament. Under the old dispensation, the tabernacle and the temple were constituted to be, asserts Owen, 'the place of all sacred and solemn worship' (Owen Works I: 253).

There is a clear link here between the order and things of the Old Testament worship and the one Christ mediates in heaven. The Lord Jesus Christ before the throne of grace mediating on behalf of the church, the presence of angels and the spirits of men around the throne, were all obscurely represented in the order of the church at its first erection in the wilderness. Owen explains that the ordinances of God among them were patterns or figures of heavenly things (Hebrews 9:23). The tabernacle in the midst represented the sanctuary or the temple above. The ark and the mercy seat from the most holy place are representative of the throne of grace; the ministry of the high priest is a type of the ministry of Christ in heaven; the Levites, who attended on the priest, did represent the ministry of angels attending on Christ in the discharge of his office. And round about them were the tribes in their order (Owen Works I: 257).

A similar relationship with the Old Testament is likewise established by Owen when he describes the way in which our High Priest offers the worship of the people of God before God. The possibility of its access to God being hindered is secured by three things in the sacerdotal office of Christ: the influence of his oblation, the efficacy of his intercession and the dignity of his person (Owen Works I: 258-259). These are all typified by what Aaron has done in the old administration of worship before God.

So once Owen elaborates on the place and manner in which Christ mediates, he continues to show the nature of that place. Heaven is shown by 
Owen to be more than a place, it is God' throne, it is a temple where God dwells in majesty, power, grace and mercy.

The heavenly high priesthood of Christ means, therefore, that Christ appear in the presence of God at the right hand of the throne of the majesty in the heavens to present himself as the perfect high priest. This is a ministry directed for us, the church, in the real presence of God, the Father. We have asserted this already, but our present intention is to show how does Owen proves that Christ mediates for his own only, for the elect, for the redeemed church?

By asking this question we come to consider what proofs Owen has when he asserts that Christ mediates for his own only.

Owen supports this view by appealing to the Old Testament Levitical priesthood, which he regards as a type of Christ (Owen Works XVIII: 159160). While the Levitical priests had to perform a variety of procedures during sacrifices, Owen regards this as God's accommodation to earthly limitations which prevents the whole richness of Christ's priestly acts from being represented by a single type (Owen Works XXII: 231). This unity is also expressed in relation to the particularity of Old Testament sacrifices:

The blood was offered [by the Levites]... for the people of God, the Church, the whole congregation. And as the high priest herein bore the person of Christ, so did this people of all the elect of God, who were represented in them and by them. It was that people, and not the whole world, that the high priest offered for; and it is the elect people alone for whom our great high priest did offer and doth intercedes (Owen Works XXII: 232).

Thus, Owen's profound sense of the continuity between the Old and New Testaments, and the typical-antitypical relation of Levitical sacrifice to that of Christ, provides a further confirmation of the particularity of the atonement. As the Levites only offered sacrifices for the people of Israel, so Christ only offers intercession for the church. Levitical sacrifices are particular in scope, because the sacrifice of Christ, which they foreshadow and upon which they depend, is particular.

From Christ Owen takes the focus and place it on the kind of ministry Christ performs and the effects which that ministry has.

Owen continues to expand on this subject showing that Christ exercises a ministry of love, compassion, pity and care. Once again Owen stresses that the beneficiary of this ministry is the church and Christ acts as its representative (Owen Works I: 254). Dealing with the same subject Murray calls this ministry 'The Sympathy of Christ' (Murray 1958: 7). Both Murray and Owen quote from Hebrews 2:17, 18; 4:14, 15 and make it clear that this sympathy is derived from the experience of trial and temptation which Christ endured during his humiliation. The heavenly exercise of his office is 
based upon the accomplishments of his earthly ministry in the days of his flesh. In this instance the particular aspect of the earthly ministry upon which the heavenly is based is that of the sufferings and temptations to which he was subjected while on earth. It is the experience derived from these sufferings and temptations that equips him with fellow-feeling or sympathy so that he is able to support and help his own people in their sufferings and temptations.

The Johannine writings explain the same activity making use of a different term. In 1 John 2:1 the apostle informs us that in heaven 'we have an advocate (paraclete) with the Father, Jesus Christ the righteous'. The paraclete is the person who is called to help, to comfort, to support. So, Jesus in heaven is the pleader, the helper, the comforter of those who come to God through Him. This can be argued very well from the analogy of the teaching in the epistle to the Hebrews, particularly that Jesus appears in the presence of God for us and gives out support in his capacity as the high priest, touched with a feeling of our infirmities.

Christ's priestly ministry in heaven is, therefore, on behalf of men. Directed to the Father this ministry has no relevance except as he is appointed for men in things pertaining to God. But since it is a ministry on behalf of men, it is also a ministry which reaches to men in that it involves the administration of the house of God upon earth and the care of assistance to the people of God in all their temptations and tribulations.

All this is done by Christ in the presence of God and before the throne of grace with three purposes well established. Owen lists them briefly and says that (1) it is to make effectual the atonement he has made for sin, (2) to plead the believers' cause against all the accusations of Satan and (3) to intercede for them so that all the supplies of the Spirit to be given to them. [Owen makes a distinction between the means used to remove the enmity between God and us and the means to remove the enemies of the Church: sin, death and Satan. The former is done through the blood of his cross and the latter is done through his power. These were all committed to the Son in his incarnation and mediation (Owen Works I: 236).]

Thus, we understand that Christ's session in heaven means intersession. Paul is careful to remind us that in conformity with Christ's death, resurrection and session at the right hand of God is the fact that 'he also makes intercession for us' (Romans 8:34, cf. Hebrews 7:25).

Murray explains once again that these petitions surely indicate the lines along which the heavenly intercession proceeds. By good inference, therefore, from some of the recorded intercessions, we may gather something of the direction which the heavenly intercession follows.

In Romans 8:34 there are clear indications that the intercession is for the purpose of assuring believers that there is a concern on the part of the ex- 
alted Lord that none of the assaults upon them will be successful in breaking the bond that unites them to him. Due to his intercession in heaven the believers will be more than conquerors in every engagement with their adversary. In a word, it is an intercession directed to every requirement of their warfare and therefore to the supply of grace for every need.

Likewise, in Hebrews 7:24, 25, the thought is clearly to the effect that Christ is able to save to the uttermost, because he has an unchangeable priesthood and ever lives to make intercession. The intercession is mentioned more specifically as that which insures salvation to the uttermost (Murray 1958: 12).

Both 1 John 2 and Hebrews 2:17, 18 are directly related to the propitiation which Jesus Christ has performed and which he continues to be for ever. In conclusion, the activity as paraclete should most suitably be viewed as pre-eminently priestly activity based upon his finished priestly action in making propitiation.

But our next interest falls on the question related to the manner of Christ's ministry.

Owen emphasizes repeatedly that it is a glorious ministry, because it takes place in the presence of God. At present, it is a solemn instituted worship, by God's special appointment in and by Christ the mediator, which will cease at the end of the world (Owen Works I: 254). Through this ministry all the saints above, called also the church triumphant, give glory to God. It is a church-state which is constituted through this ministry. Such a state shall not be eternal, but has its time allotted to it, says Owen.

In the same time the believers on earth, also called the church militant, have, by faith, an admission in the communion with the church above, in all its divine worship. This is clearly expressed by the apostle in Hebrews 12:22-24. Here Owen speaks about an inter-relationship existed between the church below-the Zion, the name of the church-state of the Old Testament-and the heavenly Jerusalem where are all the angels, the spirits of just men made perfect in themselves. In this holy assembly and worship we have a communion through faith and love, the bond and centre between us and them being the person of Christ, as explained in Hebrews 10:19-22 (Owen Works I: 255, 259, 260; 268-269).

The solemn worship of God in the sanctuary above consists, says Owen, in an acknowledgement of God's glorious infinite wisdom, goodness, grace and power. An acknowledgement of the glorious redemption, sanctification and salvation of the church by Jesus Christ. The nature of such worship is not carnal and is not merely mental or transmitted only in the silent thoughts of each individual. Although we do not know well, says Owen, how angels and the spirits of just men communicate in heaven, the manner of it 
is such that through it the whole assembly above do jointly set forth and celebrate the praises of God (Owen Works I: 256).

Owen takes us to another important aspect of Christ's ministry in heaven. He asserts that the presence of our Lord in heaven is in his human nature. It's important to recognize the reality of our Lord's human nature in heaven and that it is in human nature that the Son of God in heaven exercises his heavenly priesthood. We must remember as well that Christ's human nature in heaven cannot be conceived of apart from the progressive developments which characterized that human nature on earth and which condition the state of consciousness, feeling and will of that human nature in heaven (Owen Works I: 257; Murray 1958: 8).

In this solemn assembly before the throne of grace, the Lord Jesus Christ-namely, the great High Priest-represents and renders acceptable to God the worship of the church here below. This is expressed for Owen in Revelation 8:3 and 4. Those verses are for Owen a clear representation of our High Priest who is the only One able to approach the altar to offer incense on it and the prayers of all the saints. This later expression is defined by Owen as 'a synecdochical expression of the whole worship of the church' (Owen Works I: 258).

Therefore, Owen concludes that in him and by him alone we represent all our desires and prayers and whole worship to God.

All the effects of the offices of Christ, internal, spiritual and eternal, in grace and in glory, - all external fruits of their dispensation in providence towards the church or its enemies-are wrought by divine power. Owen picks up another important and wonderful thing. He shows that through Christ's entrance into the heavenly sanctuary all those Old Testament saints have been given to understand 'the mystery of the wisdom and grace of God in their redemption and salvation by Christ'. [For the way in which Owen explains the difference in understanding of the mysteries of salvation between the Old and New Testament believers, see Owen (Works I: 265-66).] All they have prayed for, longed for, and desired to see in the days of their flesh on the earth, and waited for so long in heaven, was now gloriously manifested towards them.

As Owen concludes of what he has to say about Christ's mediatorial office in heaven, he resumes everything in the following words:

All the present faith and worship of God in the church here on earth, all access unto him for grace, and all acceptable ascriptions of glory unto his divine Majesty, do all of them, in their being and exercise, wholly depend on, and are resolved into, the continuation of the mediatory actings of Christ in heaven and glory (Owen Works I: 271). 


\section{Discussions in Modern Trends. R. T. Kendall's View on Christ's Atonement for All People and His Mediatorial Work in Heaven only for the Believers}

From our study of Owen so far it becomes evident that the understanding of Christ's priesthood is reflected in his emphasis upon the fact that Christ both dies and intercedes for the same group of people, the elect. This is what Owen says when he talks about the unity between Christ's oblation and intercession:

His intercession in heaven is nothing but a continued oblation of himself. So that whatsoever Christ impetrated, merited, or obtained by his death and passion, must be infallibly applied unto and bestowed upon them for whom he intended to obtain it; or else his intercession is vain, he is not heard in the prayers of his mediatorship (Owen Works X: 90).

This teaching has been in more recent times opposed by various exponents of theology. One of these exponents is R. T. Kendall who in one of his works (Kendall, 1981) suggests that Christ has died for all people but mediates in heaven only for the elect. This represents, of course, a different view and therefore departs itself from what Owen has taught and was presented in our study above. In fact, it attributes to Kendall a unique interpretation, because, according to Kendall, only part of the provision of salvation in Christ was universal in its intent, namely, his death, while his intercession was particular.

Paul Helm, who later refuted Kendall's view, qualifies these assertions as novel to an extent 'that it is difficult to find it mentioned, even in passing, in the voluminous literature of the seventeenth century, much less is it possible to find it attributed to Calvin' (Helm 1982: 36). Let us resume what Kendall has to say on this subject.

We shall have to focus our attention on chapter 3 from his book. Kendall suggests in his study that the theology of the Puritans has departed significantly from the theology of John Calvin. Calvin believed, asserts Kendall, 'that Christ died indiscriminately for all men' [Kendall makes this assertion based on Calvin's Institutes and his sermons on Isaiah (Kendall 1981: 13) but all his sufferings for the salvation of the human race remain useless until faith is given. According to Kendall's view the origin of this saving faith is 'in the intercessory work of Christ at the Father's right hand' (Kendall 1981: 13). He concludes, therefore, that while Christ died for all he does not pray for all in heaven. In his view, Christ must have died for all otherwise we could have no assurance that our sins have been expiated in God's sight (Kendall 1981: 14). When Christ's death is understood to be for all, says Kendall, it becomes a 'pledge' that God loves us. But when it is viewed to be 
efficacious only for those whom God had chosen by his secret decree, then, it obviously ceases to be a pledge to all.

When Kendall extends his comments to Theodore Beza (1519-1605), Calvin's successor in Geneva, whose fundamental doctrine of faith was his belief that Christ died for the elect only, he criticises him for a doctrine which 'inhibits the believer from looking directly to Christ's death for assurance' (Kendall 1981: 29). As much as our salvation is concerned we should learn to look, says Kendall, not to God's secret decree, but to Christ's death.

For Kendall, the decree of election is not rendered effectual in Christ's death, but in his ascension and intercession at the Father's right hand. If the decree of election would have been rendered effectual by the death of Christ, it would mean that Christ did not die for the whole world after all or since he died for all, all are elect. In other words, says Kendall, if the decree of election is rendered effectual by Christ's death, those for whom Christ died must be saved.

But Calvin, maintains Kendall, thinks that Christ died for all and yet all are not saved. If this is the case, as far as Kendall is concerned, it means that while Christ died on earth, the power and efficacy of his death comes from heaven. While Christ died for all on earth in heaven he does not pray for all the world; such intercession is for the elect only. Christ's entrance into the presence of the Father is an act through which he carries out the decree of election. The result of such intercession is faith. Kendall says: 'Faith to Calvin then is not only the ultimate consequence of election, but the immediate result of the simultaneous work of Christ at the Father's right hand and the internal testimony of the Spirit' (Kendall 1981: 19). Analysing Calvin, Kendall continues to assert that God justifies us by the intercession of Christ and that intercession, in turn, brings us to the apprehension of God's mercy. Faith may be described as merely witnessing what God has already done in Christ.

Kendall's view has been vigorously opposed by Paul Help in his work Calvin and the Calvinists (Helm 1982) which endeavours to prove that Calvin and the Puritans were theologically speaking, at one, 'and thus to support the truism that Calvin was a Calvinist' (Helm 1982: Preface).

Using the answers provided by the Reformed churches, Paul Helm seeks to explain that 'Christ died, not for all men but for the church, for those elected from eternity and given to Christ' (Helm 1982: 2). But in Calvin's view this does not mean that the message of God's reconciliation through Christ ought not to be preached and taught to all men indiscriminately, for Christ taught both that he laid down his life for his sheep (John 10) and also that the gospel is to be preached to every nation (Matthew 28:18-20).

On the cross, maintains Helm, Christ suffered as the substitute or representative of his people. He was chiefly a suffering priest, 'sent in the Father's 
love to redeem the ungodly and undeserving by interposing himself in their place' (Helm 1982: 2).

But this tradition has been opposed, says Helm, by different writers, one of them being Kendall, who has presented a changed view of the atonement and changed view of faith (Helm 1982: 7). If Kendall is right, suggests Helm, this will have practical implications on the whole nature of the Christian message. In Kendall's eyes, Puritans such as John Owen, Charles Hodge and Spurgeon have departed from the sort of Calvin that Kendall presents. If this is the case, suggests Helm, these writers are not reliable guides in the interpretation of Scripture (Helm 1982: 10).

In order to prove the opposite, Helm sets to show that Kendall's account of Calvin is inaccurate and that he provides a wildly exaggerated picture of Puritanism. He examines the writings of Calvin and discovers that the claims Kendall ascribes to Calvin are totally absent from him. Isolated phrases which seem to teach the view are seen to teach the exact opposite, or to be about something quite different (Helm 1982: 38-46).

With respect to our subject Helm proves that Christ made atonement and intercedes in heaven only for the elect. He proves that what Kendall says can be true only if what Calvin says is seriously distorted, and that to maintain Kendall's position has alarming consequences for the biblical doctrine of Christ's intercession.

When Helm sets to explain what Calvin had to say about the meaning of the expression 'Christ died for all' he proves that 'Calvin certainly held that Christ died for all men in a sense that allowed Christ to be preached to all, and all invited freely to come to him' (Helm 1982: 47). Helm explains that by approving Kendall's idea would mean that Christ by his death expiated the sins of all men, but this expiation is not itself sufficient for the salvation of any man, for in addition the intercession of Christ for the elect is necessary. According to Kendall, only those are saved for whom Christ has both died and interceded. There are some for whom Christ died, but does not intercede for them and therefore are not saved.

According to Helm, such an interpretation obscures the New Testament idea that the work of Christ is finished. He refers here to Hebrews 9:12; $7: 27 ; 9: 26$. If what Kendall suggests is true it means that the work of redemption is not finished so long as Christ continues to intercede. And the New Testament teaching is that Christ's intercession is something present and continuous (Hebrews 7:25). It is obvious once again, says Helm, that Kendall's view fails to do justice to the New Testament teaching, for it seems to make that intercession something separate from and additional to his death. The New Testament teaching is that Christ's intercession is the product or fruit of his victory over sin. It is a representation of Christ's finished work on the cross before his Father and is affected by the presence of 
Christ in heaven. What constitutes the intercession is the very triumph of Christ's death and his presence at the Father's right hand.

Helm concludes that there is no prospect of dividing up the total saving work of Christ between death and intercession, and of claiming that there are things that the intercession of Christ accomplishes that his death did not accomplish. Such claims, says Helm, 'appears to be novel and unprecedented' (Helm 1982: 35). Thus, Helm resumes that Kendall's idea that there is an important break between Calvin and the Puritans over the nature of the work of Christ is seen to be without foundation (Helm 1982: 50).

\section{Conclusions}

As we conclude our study, we feel compelled to say that we have occupied our attention with one of the greatest subjects to which we can direct our thoughts. Owen has helped us to see in much more profound way that every aspect of Christ's work is based upon an act of divine love and good pleasure in which Christ has come to us in order to restore us to fellowship with God.

We have endeavoured to understand something about the Divine counsel which stands at the basis of Owen understanding of Christ mediatorial work. In all their aspects, Owen's Christological reflections represent a restatement of orthodox Christology which stands in fundamental continuity with the Reformed tradition, particularly in its use of the threefold office of Christ.

What emerges in Owen regarding Christ as Mediator is positively shaped by the intratrinitarian relations defined by the covenant of redemption and the three-fold office of Christ as prophet, priest, and king which preserve both, the historical and the eternal dimensions.

As we focused more on the part which refers to Christ's priesthood, we have seen that Owen regards the nature of Christ's priesthood as being analogous to that of the Old Testament Levites, consisting of two basic, inseparable, elements: sacrifice and the offering of that sacrifice to God, or oblation and intercession, as he prefers to call them.

By this constant appeal to the Old Testament, Owen established beyond doubt the particular character of the atonement and intercession. As Levitical sacrifices were particular in scope, so the sacrifice of Christ which they foreshadow and upon which they depend is particular.

Thus, the Ascension of our great Head of the Church, in his human as well as his divine nature, to the right hand of God opens up to us an endless prospect of what our humanity shall yet be in him and conveys to us the assurance that whatever he desires he is able to perform. There is nothing more demanded from the church of the present day than the revival of the idea the we live in him who is our High Priest in heaven. 


\section{Bibliography}

\section{Primary sources}

Goold WH (ed) Christologia: or a declaration of the glorious mystery of the person of Christ. In The Works of John Owen, volume 1. Edinburgh: The Banner of Truth Trust.

Goold WH (ed) Meditations and discourses on the glory of Christ. In The Works of John Owen, volume 1. Edinburgh: The Banner of Truth Trust.

Goold WH (ed) A discourse concerning the Holy Spirit. In The Works of John Owen, volume 3. Edinburgh: The Banner of Truth Trust.

Goold WH (ed) A Display of Arminianism. In The Works of John Owen, volume 10. Edinburgh: The Banner of Truth Trust.

Goold WH (ed) Vindiciae Evangelicae. In The Works of John Owen, volume 12. Edinburgh: The Banner of Truth Trust.

Goold WH (ed) An exposition of the Epistle to the Hebrews. In The Works of John Owen, volume 17. Edinburgh: The Banner of Truth Trust.

Goold WH (ed) An exposition of the Epistle to the Hebrews. In The Works of John Owen, volume 18. Edinburgh: The Banner of Truth Trust.

Goold WH (ed) An exposition of the Epistle to the Hebrews. In The Works of John Owen, volume 19. Edinburgh: The Banner of Truth Trust.

Goold WH (ed) An exposition of the Epistle to the Hebrews. In The Works of John Owen, volume 22. Edinburgh: The Banner of Truth Trust.

\section{Secondary sources}

Ferguson SB (2002) John Owen and the doctrine of the person of Christ. In Oliver R (ed) John Owen: the man and his theology. Darlington \& Phillipsburg: Evangelical Press and P\&R.

Helm P (1982) Calvin and the Calvinists. Edinburgh: The Banner of Truth Trust.

Kendall RT (1981) Calvin and English Calvinism to 1649. Oxford: Oxford University Press.

Milligan W (1977) The ascension and heavenly priesthood of our Lord. Greenwood: Attic Press.

Murray J (1958) The heavenly priestly activity of Christ. The Campbell Morgan Bible Lectureship-Tenth Lecture: 18th June at Westminster Chapel, London.

Ton P (1984) The Ascension of our Lord. New York: Thomas Nelson.

Trueman CR (1998) The Claims of Truth. Carlisle: Paternoster Press.

[This article was published previously is Moga D (2008) Studies in Historical Theology. Oradea: Emanuel University Press, pp. 133-166.] 